\title{
Learning outcomes in the field of human resource management in business administration studies in the context of implementation of European Qualifications Framework (EQF) - examples from University of Valencia, Spain, and University of Dubrovnik,
} Croatia

\section{Vrdoljak Raguž, Ivona ${ }^{a}$ and Hernandez-Carrion, Jose-Rodolfo ${ }^{b}$}

${ }^{a}$ Department of Economics and Business Economics, University of Dubrovnik, Croatia ${ }^{\mathrm{b}}$ Department of Applied Economics, Faculty of Economics, University of Valencia, Spain

\begin{abstract}
The study carried out in this paper involves the analysis of the content of the competencies in the field of human resource management in order to acquire the key competencies of the students that will be aligned with the needs of the labour market according to the European Qualifications Framework (EQF). The method of comparative analysis and case study methodology is used in the paper. This research compares teaching courses that include the acquisition of competencies in the field of Human Resource Management in business administration studies, one of the key areas of contemporary management, with examples from the Department of Economics and Business Economics of the University of Dubrovnik (Croatia) and the Faculty of Economics of the University of Valencia (Spain). The study may be a contribution to better alignment and compatibility between study programs of economics and management in the countries and beyond. In order to get answers to the research questions, the paper analyses the learning outcomes of the two observed universities.
\end{abstract}

Keywords: European Qualifications Framework; EQF; Learning Outcomes; Human Resource Management; University of Valencia; University of Dubrovnik. 


\section{Introduction}

This paper explores the study content of Economics and Business Economics studies at the University of Valencia in Spain and University of Dubrovnik in Croatia in the context of achieving the principles set out in the Bologna Declaration, based on the European Qualification Framework (EQF).

In the paper authors deal with the consistency of the learning outcomes between individual courses in the area of Human Resource Management at the University of Valencia and the University of Dubrovnik, using the method of comparative analysis and case study methods. Examples of case studies are presented from the Faculty of Economics of the University of Valencia and the Department of Economics and Business Economics of the University of Dubrovnik.

The key starting points for this research are as follows: multidisciplinary approach, understanding usage of human resource management as a critical factor for the company's competitiveness, but also the success of each organization and the necessity of linking key competencies of students with needs in the labour market, as well as the mutual alignment of competencies acquired in individual courses in Economics and Business Administration, and Business Economics studies, both horizontally and vertically.

\section{European Qualification Framework and Higher Education}

The recommendation of the European Parliament and later the Council of $23^{\text {rd }}$ April 2008, on the establishment of the European Qualifications Framework for lifelong learning, created a common reference framework of eight levels of qualifications, expressed as learning outcomes with increasing levels of proficiency. The purpose of the European Qualifications Framework for lifelong learning (EQF) is to improve the transparency, comparability and portability of people's qualifications. The EQF is a common European reference framework which links countries' qualifications systems together, acting as a translation device across different countries and systems in Europe.

Council Recommendation of $22^{\text {nd }}$ May 2017 on the European Qualifications Framework for lifelong learning and repealing the recommendation of the European Parliament and of the Council of $23^{\text {rd }}$ April 2008 on the establishment of the European Qualifications Framework for lifelong learning (2017/C 189/03), is the reference, published in the Official Journal of the European Union. The goals (outcomes) of the process of adopting the study program learning outcomes and acquired competencies are implemented in EQF and they serve as a translation device between different qualifications systems and their levels. 
Learning outcomes and study contents need to be constantly adapted to socio-economic changes. Some of the most important goals of the Bologna Declaration, whose implementation process in the Croatian and Spanish higher education system is as follows: introduction of national qualifications frameworks comparable to the EHEA (European Higher Education Area and Bologna Process), define learning outcomes for all three cycles according to Dublin descriptors and quality assurance in accordance with European quality standards (Standards and Guidelines for Quality Assurance in European Higher Education).

Higher Education has looked towards the acquisition of knowledge and competences (the "learning outcome") instead of focusing on study programs and teaching hours. This implies a "paradigm shift", from teaching to learning, from the program to the "learner", from post-secondary education to lifelong learning (Lifelong Learning or LLL), from the formative itinerary to their achievements and from "diplomas" to "qualifications" (that is, the type and level of the set of competencies and knowledge that a person can demonstrate).

Learning outcomes became part of the Bologna Process after the Berlin Conference held in 2003, and its conclusions included the requirement for member states of the Bologna Process to produce a framework of comparable and compatible qualifications in their higher education systems, which will describe qualifications in terms of teaching load, level, learning outcomes, competency and profile. Ministers demanded that the European Qualifications Framework be created for the European Qualifications Framework (Čikeš, 2005). The application of learning outcomes to higher education institutions is a major challenge.

\section{Methodology and Research Results}

In order to get answers to the research questions, the paper analyses the learning outcomes of the two observed universities. As a result of this research, the paper outlines the learning outcomes of Human Resource Management courses and courses that are related to Human Resource Management (HRM) on examples of the Faculty of Economics of the University of Valencia and Department of Economics and Business Economics of the University of Dubrovnik.

The Croatian qualifications framework (CROQF) Act (Ministry of Science, Education and Sports, 2013) establishes the CROQF based on learning outcomes, defined in terms of knowledge, skills and responsibility and autonomy. It is a single, comprehensive eight-level framework, which incorporates credit systems. It includes qualifications from all levels and subsystems of formal education and training (general education, VET and higher education); it will also be the basis for validating non-formal and informal learning. Apart from offering transparency, the CROQF is seen as an important tool for reforming national 
education and training; this includes setting up a system for validating and recognising nonformal an informal learning, and creating a well-founded quality assurance system (CEDEFOD, European Center fo the Development of Vocational Trainig (2015). National Qualifications Framework Developments in Europe. Retrieved April 19, 2018, from http://www.submeet.eu/european_library/EQF_in_Europe.pdf).

The research carried out for Croatian University of Dubrovnik set in the context of the CROQF (Croatian qualifications framework) and is compared to the results of the ECONQUAL project aimed at "contributing to the process of redefining and reviewing learning outcomes relevant to changes in the social, political, economic and technological environment". The ECONQUAL project was a necessary step towards creating a sustainable higher education system in the field of economics to the satisfaction of employers, students and higher education teachers (ECONQUAL, 2016). The aim of the project was to "improve the quality of higher education of economists through the development of qualification standards in the field of economics", while the specific objectives of the project were "to develop a qualification standard for the economy and business economy in a higher education system; criteria for innovation and improvement of study programs at economic faculties" (ECONQUAL, 2016).

In Croatia at the majority of public state universities at the Faculties/Department the study programmes are $3+2$, only one is $4+1$ and one study programme is integrated $5+0$.

Learning outcomes of the Human Resource Management Course at the Department of Economics and Business Economics of the University of Dubrovnik. After attending the course and passed the exam, the students will be able to:

- independently design and conduct basic human resource management tasks in all enterprise categories

- analyse internal and external human resource management environment

- understand the concept of strategic human resource management

- understand job analysis issues, systematize the student's postgraduate course and exam

- differentiate the concept of training from the concept of employee development

- apply models, methods, techniques and HR management programs in business practice (planning, attracting, selecting and orienting human resources)

- addressing practical human resource management skills in organizations (work performance management, professional career through work and compensation).

Courses at the undergraduate and graduate level at the Department of Economics and Business Economics of the University of Dubrovnik that are related to the course Human 
Resource Management are: courses at the undergraduate study (Basics of Management, Sales Management, Change Management, Operations Management) and courses at graduate study (Corporate Governance, Marketing Management, Strategic Marketing Management, Strategic Management, International Business Negotiation, Brand Management, Business Leadership, Quality Management, Controlling). Also at the study Economics programme is a very important course that one related with Human Resource Management in Labour Economics.

In the Spanish case, the National Agency for the Evaluation of Quality and Accreditation (ANECA) is a state foundation created in 2002, in compliance with the provisions of the Organic Law of Universities, which aims to contribute to the improvement of the quality of the higher education system through the evaluation, certification and accreditation of teaching, teaching staff and institutions. ANECA develops different programs to carry out its evaluation, certification and accreditation activity), in order to integrate the Spanish system into the European Higher Education Area (EHEA), although most regions or Autonomous Communities have created their own "regional" quality assurance organizations (Agència Valenciana d'Avaluació i Prospectiva or AVAP in Valencia region).

The main programs developed by ANECA are: 1.-VERIFICA: evaluates the proposals of the study plans designed in accordance with the objectives established for the construction of the European Higher Education Area. 2.-MONITOR: monitors a verified program until it must be presented again to renew its accreditation. 3.-ACREDITA: performs an assessment for the renewal of the initial accreditation of official degrees.

Unlike other countries of the EHEA where the structure of degrees and masters is no longer a topic of university policy, in Spain the RD of 2015 reopens the issue of $3+2$ and $4+1$ and carries the risk that universities spend their energy in structural aspects instead of investing in more strategic reforms, such as curricular and methodological renewal, lifelong learning, improved governance and university funding, the promotion of innovative capacities of universities and its competitiveness in the European and global sphere.

Degree in Business Administration and Management is analysed according to its subjects for Human Resource Management Curriculum (Human resource management tools, Work psychology, Labour economy, Pay incentives and systems, Negotiation techniques and economic applications, Supplementary pension systems, Labour and trade union law, Sociology of organizations, Strategic management of human resources).

Two famous new concepts arrive: "learning outcomes" and "competences", both used with different shades of meaning and in somewhat different frames of reference. In all cases they are related to what the learner supposedly will know, understand and be able to do at the end of a learning experience (Hernandez-Carrion, 2011, p. 147). At University of Valencia three competences types are established for every degree: Basics, General and Specific 
ones. We focus only on Basic Competences (Competencias Basicas = CB, Faculty of Economics, University of Valencia, Spain (Retrieved February 8, 2018, from https://www.uv.es/uvweb/economy/en/faculty-economics-1285848977403.html).

- CB1 - Students must have acquired knowledge and understanding in a specific field of study, on the basis of general secondary education and at a level that includes mainly knowledge drawn from advanced textbooks, but also some cutting-edge knowledge in their field of study.

- CB2 - Students must be able to apply their knowledge to their work or vocation in a professional manner and have acquired the competences required for the preparation and defence of arguments and for problem solving in their field of study.

- CB3 - Students must have the ability to gather and interpret relevant data (usually in their field of study) to make judgements that take relevant social, scientific or ethical issues into consideration.

- CB4 - Students must be able to communicate information, ideas, problems and solutions to both expert and lay audiences.

- CB5 - Students must have developed the learning skills needed to undertake further study with a high degree of autonomy.

There are also three different competences for Master degree, three different competences always for every degree: Basics, General and Specific ones. Basic Competences are:

- CB1: That the students know how to apply the acquired knowledge and their ability to solve problems in new or unfamiliar environments within broader (or multidisciplinary) contexts related to their area of study.

- CB2: That students are able to integrate knowledge and face the complexity of making judgments based on information that, being incomplete or limited, includes reflections on social and ethical responsibilities linked to the application of their knowledge and judgments.

- CB3: That the students know how to communicate their conclusions and the knowledge and reasons that support them, to specialized and non-specialized publics in a clear and unambiguous way.

- CB4: That the students have the learning skills that allow them to continue studying in a way that will be largely self-directed or autonomous

- CB5: Possess and understand knowledge that provides a basis or opportunity to be original in the development and / or application of ideas, often in a research context. 
A different one is the degree in Labour Relations and Human Resources. Also we find three competences for every degree: Basics (CB), General and Specific ones; the CB are:

- CB1 - Students must have acquired knowledge and understanding in a specific field of study, on the basis of general secondary education and at a level that includes mainly knowledge drawn from advanced textbooks, but also some cutting-edge knowledge in their field of study.

- CB2 - Students must be able to apply their knowledge to their work or vocation in a professional manner and have acquired the competences required for the preparation and defence of arguments and for problem solving in their field of study.

- CB3 - Students must have the ability to gather and interpret relevant data (usually in their field of study) to make judgements that take relevant social, scientific or ethical issues into consideration.

- CB4 - Students must be able to communicate information, ideas, problems and solutions to both expert and lay audiences.

- CB5 - Students must have developed the learning skills needed to undertake further study with a high degree of autonomy.

\section{Discussion}

The significance of Human Resources Management (HRM) is that it reflects the capacity to attract and retain a stable, qualified workforce, making it the greatest asset for achieving positive results for its economy and future. The Bologna Declaration of 1999 has put in motion a series of reforms needed to make European Higher Education more compatible and comparable. Our paper analyses the learning outcomes of the two observed universities, University of Valencia, Spain, and University of Dubrovnik, Croatia; "learning outcomes" and "competences" are related to what the learner supposedly will know, understand and be able to do at the end of a learning experience.

Learning outcomes describe significant learning that learners have achieved, and can be demonstrated at the end of a course or program. There are no rules on how many outcomes are appropriate per lecture course or credit point and standardisation would be artificial. Some courses may have many outcomes that are easily achieved. Other, may have more complex outcomes which are more demanding to acquire.

In this paper it is also shown that even though the same course is analysed, there are a lot of differences between the learning outcomes and connections with other courses that are part of the curriculum of the study programme of the analysed universities which is the proof of heterogeneity of the study programmes between different countries and universities in EU. 


\section{Concluding Remarks and Recommendations for Future Research}

This paper presents a contribution to the analysis study programs of Economics and Business Economics in the contemporary socio-economic context. The research area refers to study programs in Economics and Business Economics in Spain and Croatia. The broader role of this field of study is also to examine the role and significance of the study of management in contemporary socio-economic conditions. The paper emphasizes the necessity of deeper insight and holistic approach to human resource management issues in organizations, especially in the context of relevant contemporary socio-economic developments.

The paper contributes to better compatibility among the study programs of Economics and Business Economics in the country and abroad. As a possible limitation of research it should be emphasized that in the research are not included those courses whose content is indirectly related to the course Human Resource Management. Moreover it can be a guide for further research that could focus on the real needs from basic competences: impact, role of professionals, market value of competences, and implications for globalization; and may also be aimed at further research on the logical and substantive connectivity of the study programs studied at the two universities examined. It will be interesting to include in future research more universities from different countries of the European Union and make the comparison.

\section{References}

Čikeš, N. (2005). Kvalifikacije i kompetencije u europskom prostoru visokog obrazovanja, Tempus projekt: Prvi koraci u Bolonjskom procesu, Zagreb, Sveučilište u Zagrebu.

CEDEFOD, European Center fo the Development of Vocational Trainig (2015). National Qualifications Framework Developments in Europe. Retrieved April 19, 2018, from http://www.submeet.eu/european_library/EQF in Europe.pdf

ECONQUAL - Katalog zanimanja (2016). Istraživački rezultati Projekta ECONQUAL, Ekonomski fakultet Sveučilišta u Rijeci, Rijeka. Retrieved October 29, 2017, from https://www.efri.uniri.hr/hr/econqual/187_187

Elken, M. (2015). Developing policy instruments for education in the EU: the European Qualifications Framework for lifelong learning, International Journal of Lifelong Education, Vol. 34(6), 710-726. https://doi.org/10.1080/02601370.2015.1103795

Hernandez-Carrion, J. R. (2011). English language for successful integration: Learning from the Bologna Process. Annals of the University of Oradea: Economic Sciences, Vol. 20(2), 140-147. https://doi.org/10.5281/zenodo.1222075 